Jurnal Ilmu Dan Teknologi Kesehatan

Vol 8, No 2, March 2021,

ISSN: 2338-9095 (Print)

ISSN: 2338-9109 (online)

\title{
Different Effectiveness of Dry Needle with Laser After Myofascial Release Added on Complaints of Myogenous Back Pain
}

\author{
Saifudin Zuhri, Marti Rustanti \\ Poltekkes Kemenkes Surakarta, Indonesia \\ Email: zuhriphysio@gmail.com
}

\section{Article history}

Posted, Dec 16th, 2020

Reviewed, Jan 20th, 2021

Received, March 15th, 2021

\begin{abstract}
Low back pain (LBP) complaints are prevalent that many people experience daily. Dry needling physiotherapy technology for myogenic LBP complaints has not been widely used in the clinical setting than laser. In contrast, it turns out that the application of laser for pain cases was not effectively socialized. In this study, the efficacy of dry laser needling was compared after the addition of myofascial release for myogenic LBP complaints. The research method was experimental study used two groups before and after the test design. The subjects were determined by reasoned sampling. The subjects were all patients with complaints of myogenic LBP who met the research criteria. The number of subjects in group I was 37 subjects, and group II was 36 subjects with myogenic LBP. The research was conducted from March to October 2020 at Sunafa physiotherapy practice, Colomadu, Karanganyar. There was a significant effect of dry needling with the myofascial release on pain reduction in patients with myogenic $L B P(p=0,000)$. Also, there was a significant effect of laser with the myofascial release on pain reduction in patients with myogenic LBP $(p=0,000)$. Dry needles and laser after adding myofascial release effectively reduce pain in patients with myogenic LBP.
\end{abstract}

Keywords: dry needle; laser; myofascial release; myogenic LBP complaints; pain.

\begin{abstract}
ABSTRAK
Keluhan nyeri punggung bawah (LBP) lazim dialami banyak orang setiap hari. Teknologi fisioterapi dry needling untuk keluhan LBP miogenik belum banyak digunakan dalam pengaturan klinis daripada laser. Sebaliknya, ternyata penerapan laser untuk kasus nyeri kurang disosialisasikan secara efektif. Dalam studi ini, kemanjuran tusuk jarum laser kering dibandingkan setelah penambahan pelepasan myofascial untuk keluhan LBP miogenik. Metode penelitian adalah studi eksperimental dengan menggunakan dua kelompok sebelum dan sesudah rancangan tes. Subjek penelitian adalah semua pasien dengan keluhan myogenic LBP yang memenuhi kriteria penelitian. Jumlah subjek pada kelompok I sebanyak 37 subjek, dan kelompok II sebanyak 36 subjek dengan LBP miogenik. Penelitian dilaksanakan pada bulan Maret hingga Oktober 2020 di tempat praktek fisioterapi Sunafa, Colomadu, Karanganyar. Ada efek yang signifikan dari tusuk jarum kering dengan pelepasan
\end{abstract}


myofascial pada pengurangan nyeri pada pasien dengan LBP miogenik ( $p=0,000)$. Juga, ada efek yang signifikan dari laser dengan pelepasan myofascial pada pengurangan nyeri pada pasien dengan LBP miogenik $(\mathrm{p}=0,000)$. Dry needling dan laser setelah ditambahkan myofascial release secara efektif mengurangi rasa sakit pada pasien dengan LBP miogenik.

Kata kunci: dry needling; laser; myofascial release; LBP miogenik; nyeri.

\section{INTRODUCTION}

Low back pain complaints (low back pain) is a prevalence that is experienced by many people who go about their daily activities. Physiotherapy technology for myogenic low back pain complaints in dry needling has not been widely used in the clinical setting than laser. In contrast, it turns out that the application of laser for pain cases was not effectively socialized. In terms of incidence of low back pain (Maher et al., 2017), while the effectiveness of dry needling ( $\mathrm{Hu}$ et al. 2018) and laser (Nambi et al., 2018) is indicative of conditions pain, including low back pain.

\section{METHOD}

This study was an experimental study with a two-group design before and after the test. The subjects were determined by reasoned sampling. The criteria for this study were: (1) inclusion criteria, (2) exclusion, and (3) discontinuation.

The inclusion criteria included: (a) subjects complaining of myogenic low back pain, (b) aged 18 to 70 years, (c) willing to be subjects. Exclusion criteria included: (a) myogenic low back pain followed by other disorders, (b) sensitivity is altered, (c) there is a malignancy in the lower back, (d) fear of needles. Criteria for discontinuation included: (a) not participating in the therapy program> once, (b) feeling a worsening condition, (c) not being present in the final study assessment. The subjects' method was grouped into two groups: the group with dry needling and myofascial release. Meanwhile, Group II received a laser and myofascial release.

Odd-sequence myogenic LBP subjects were included in group I, and evensequence subjects were included in group II, and so on. Each subject received therapy three times in a row for three days. Before treatment was administered, each subject was measured for pain as a baseline (pre-test), and after third therapy, each subject was assessed for pain as post-test data. The number of subjects in group I was 37 people, and group II was 36 people with myogenic low back pain. The research was conducted from March to October 2020 
at Sunafa physiotherapy practice, Colomadu, Karanganyar. This research was conducted with a description of ethical ethics

No. slightly more painful, i.e., $0.74 \mathrm{~mm}$ difference from the visual analog scale (VAS) range of $0-100 \mathrm{~mm}$, so there was very little difference in the value of the difference in pain level.

According to research (Zelin, Fatmawati \& Sulistyaningsih, 2019), it is shown that there is a relationship between age and gender variables in low back pain complaints. Age, in this case,> 30 years and sex, especially women. The mean age of the two groups was also over 30, and both groups' predominance was female. The distribution of the subjects' characteristics showed balanced proximity. The initial data was tested for data normality, and the result was that there was an abnormal distribution of the data, so that it was tested nonparametrically.

Table 1. VAS rate between two group

\begin{tabular}{ccc}
\hline Group & Initial VAS & Final VAS \\
\hline I & 0.20 & 0.02 \\
\hline II & 0.53 & 0.87 \\
\hline
\end{tabular}

From the test results of dry needling with the myofascial release was found to reduce pain in patients with myogenic low back pain $(p=0,00)$. In this study, treatment of dry needles and myofascial release was found to affect reducing pain. The needle is inserted at the pain trigger points (trigger points) in the lower back region's muscles, which will trigger the release of endorphins as a pain inhibiting neurotransmitter. Inhibition of pain at the synapse, i.e., Beta-endorphins, produce analgesia by binding to nerve endings of opioid 
receptors, primarily exert their effect through presynaptic binding (SprouseBlum et al., 2010).

It is consistent with Butts (2016), who reported that dry needling might improve opioid-based pain, mediated by endogenous cannabinoids and the sympathetic nervous system, and non-pain relief. Opioid via brainstem serotonin and norepinephrine. Dry needling also triggers a centralized hypothalamic-pituitaryadrenaline axis, and corticotropin releases a hormone-proopiomelanocortin corticosteroid axis locally to inhibit cox-2, thereby reducing inflammatory cytokines. This study is in line with research (Mahmoudzadeh et al., 2016), which reported that dry needling interventions could significantly reduce pain.

Itoh et al. (2011) demonstrated the principle of dry needling application, and several studies concluded that the depth of needle penetration is essential in relieving muscle pain. Dry needling will improve blood circulation with vasodilating action due to algogenic pain - especially prostaglandins, which will be secreted in the event of injury, including minor injuries due to puncture. Various studies have shown that dry needling can improve muscle blood circulation and oxygenation (Cagnie et al., 2013). It is consistent with a meta-analysis study by Rodríguez-
Mansilla et al. (2016), which reported that out of 19 potentially relevant clinical trials, a total of 10 were included in the meta-analysis, regarding a reduction in 1 Pain intensity when measured before and immediately after the procedure, dry needling provided an improvement over placebo treatment.

Meanwhile, myofascial release to myogenic low back pain complaints will contribute to the breakdown of trigger points due to the myofascial release technique, resulting in optimal lengthening and tense muscles (Boyajian-O 'Neill and Cardone, 2008) in the lower back area. Due to the lengthening and relaxation of the lower back muscles, the blood circulation becomes fluid. The local metabolism becomes optimal so that the pain is reduced or even lost. As is known, among the causes of pain due to muscle tension is the accumulation of lactic acid, so the tissue undergoes acidosis. The acidic tissue will sensitize the nociceptors, causing pain. When the blood circulation becomes regular, the circulation of metabolites is also regular. So that the blood supply is sufficient, the accumulation of lactic acid can be transported. The tissue is not acidic, the sensitization of nociceptors is reduced and even lost so that the pain is reduced 
and even lost (Boyajian-O'Neill \& Cardone, 2008). In line with research by Ajimsha et al. (2014), this study provides evidence that myofascial release, when used in addition to specific back exercises, is more effective in reducing pain than control interventions. Chronic low back pain in professional nurses.

There is an effect of laser with the myofascial release on pain reduction in patients with myogenic low back pain $(\mathrm{p}=$ $0.00)$. There is no difference in dry needles with release myofascial and laser with the myofascial release on pain reduction in patients with myogenic low back pain. In this study, laser treatment and myofascial release also showed an effect in reducing pain. Low-level laser therapy has been used in various medical therapies. The laser has a positive impact on energy metabolism (Heu et al., 2013). The laser is given to the pain area of the muscles of the lower back region, will impact, among other things, the effect of biostimulation, an improvement in blood circulation (Schindl et al., 2003), so that 'it will improve local metabolism in the lower back area. Adequacy of blood circulation and local metabolism improvement in the lower back area will reduce the tension of lower back muscles. It will facilitate all functions, including entrapment of nerves and reduced or even lost nerve awareness, so pain is reduced or even lost.

Lasers can reduce pain through one or a combination of mechanisms, namely collagen proliferation, anti-inflammatory effects, increased circulation, and peripheral nerve stimulation (Clijsen et al., 2017). The laser can reduce this pain. According to Kholoosy et al. (2020), reported that laser therapy (in combination with NSAIDs) is an effective and long-lasting therapeutic strategy for relieving low back pain without significant side effects. The myofascial release application after laser treatment on myogenic low back pain complaints will help break down the trigger points due to the myofascial release technique, resulting in optimal lengthening and relaxation of muscle contractions (Boyajian-O'Neill and Cardone, 2008) in the lower back region. Due to the lengthening and relaxation of the lower back muscles, the blood circulation becomes fluid. The local metabolism becomes optimal so that the pain is reduced or even lost.

Dry needling and laser applications, followed by myofascial release applications for myogenic low back pain complaints, have been shown to reduce pain. These two treatments in the two treatment groups were equally effective, and there was no significant difference. It 
is different from research by Agung et al. (2018). They reported that weak laser therapy effectively reduces pain in upper trapezius muscle pain syndrome than dry needling therapy. This difference is potentially obtained because this study's duration lasted four weeks and was combined with a stretch of the upper trapezius muscles. While in the study, which lasted for three days, it was associated with myofascial release, and the topical lesions were different, especially in the lower back $(\mathrm{p}=0.198)$.

Dry needling and laser applications, followed by myofascial release applications for myogenic low back pain complaints, have been shown to reduce pain. These two treatments in the two treatment groups were equally effective, and there was no significant difference. It is different from research by Agung et al. (2018). They reported that weak laser therapy effectively reduces pain in upper trapezius muscle pain syndrome than dry needling therapy. This difference is potentially obtained because this study's duration lasted four weeks and was combined with a stretch of the upper trapezius muscles. While in the study, which lasted for three days, it was associated with myofascial release, and the topical lesions were different, especially in the lower back.
Although the effect of dry needling is primarily inhibition of pain at the synapse (Sprouse-Blum et al., 2010) and metabolism (Cagnie et al., 2013), while the laser is from the field of collagen proliferation, anti-inflammatory effects, increased circulation, and peripheral nerve stimulation (Clijsen et al., 2017) and metabolism (Heu et al., 2013). Also, both research groups received the myofascial release, and both had a relaxing effect (Boyajian-O'Neill and Cardone, 2008) and improved metabolism (Moraska et al., 2013). The final results of the research treatment obtained the same significant painreducing effect in both groups of research subjects.

\section{CONCLUSION}

Dry needles and laser after adding myofascial release effectively reduce pain in patients with myogenic LBP.

\section{REFERENCES}

Agung, I. et al. (2018). Low-level laser therapy and dry needling for myofascial pain syndrome of the upper trapezius muscle: An interventional study. Journal of Physics: Conference Series, 1073, 062045. DOI: $10.1088 / 1742-$ 6596/1073/6/062045.

Ajimsha, M. S., Daniel, B. and Chithra, S. (2014). Effectiveness of Myofascial 
release in the management of chronic low back pain in nursing professionals. Journal of Bodywork and Movement Therapies, 18(2), 273-281.

DOI:

10.1016/j.jbmt.2013.05.007.

Boyajian-O'Neill, L. A. and Cardone, D. A. (2008). Practical Application of Osteopathic Manipulation in Sports Medicine. The Sports Medicine Resource Manual. DOI: 10.1016/B978-141603197-0.100345.

Butts, R. and Dunning, J. (2016). Peripheral and Spinal Mechanisms of Pain and Dry Needling Mediated Analgesia: A Clinical Resource Guide for Health Care Professionals. International Journal of Physical Medicine \& Rehabilitation, 04(02). DOI: 10.4172/2329-9096.1000327.

Cagnie, B. et al. (2013). Physiologic Effects of Dry Needling. Current Pain and Headache Reports, 17(8), 348. DOI: 10.1007/s11916-0130348-5.

Clijsen, R. et al. (2017). Effects of lowlevel laser therapy on pain in patients with musculoskeletal disorders: a systematic review and meta-analysis. European Journal of physical and rehabilitation medicine, 53(4), 603-610. DOI: 10.23736/S1973-9087.17.04432-X.

Heu, F. et al. (2013). Effect of low-level laser therapy on blood flow and oxygen- hemoglobin saturation of the foot skin in healthy subjects: a pilot study. Laser therapy, 22(1), 21-30. DOI: 10.5978/islsm.13-or03.

Itoh, K., Minakawa, Y. and Kitakoji, H. (2011). Effect of acupuncture depth on muscle pain. Chinese medicine,
6(1), 24. DOI: $10.1186 / 1749-8546-$ 6-24.

Kholoosy, L. et al. (2020). Evaluation of the Therapeutic Effect of Low-Level Laser in Controlling Low Back Pain: A Randomized Controlled Trial. Journal of lasers in medical sciences, 11(2), 120-125. DOI: 10.34172/j1ms.2020.21.

Maher, C., Underwood, M. and Buchbinder, R. (2017). Non-specific low back pain. Lancet (London, England), 389(10070), 736-747. DOI: $\quad 10.1016 / \mathrm{S} 0140-$ 6736(16)30970-9.

Mahmoudzadeh, A. et al. (2016). The effect of dry needling on the radiating pain in subjects with discogenic low-back pain: A randomized control trial. Journal of research in medical sciences: the Official Journal of Isfahan University of Medical Sciences, 21, 86. DOI: $\quad 10.4103 / 1735-$ 1995.192502.

Moraska, A. F. et al. (2013). Changes in blood flow and cellular metabolism at a myofascial trigger point with trigger point release (ischemic compression): a proof-of-principle pilot study. Archives of physical medicine and rehabilitation, 94(1), 196-200.

DOI: 10.1016/j.apmr.2012.08.216.

Nambi, G. et al. (2018). Spinal manipulation plus laser therapy versus laser therapy alone in the treatment of chronic non-specific low back pain: a randomized controlled study. European Journal of physical and rehabilitation medicine, 54(6), 880-889. DOI: 10.23736/S1973-9087.18.05005-0.

Rodríguez-Mansilla, J. et al. (2016). 
Effectiveness of dry needling on reducing pain intensity in patients with myofascial pain syndrome: a Meta-analysis. Journal of traditional Chinese medicine $=$ Chung $I$ tsa Chih Ying wen pan, 36(1), 1-13. DOI: $10.1016 / \mathrm{s} 0254-$ 6272(16)30001-2.

Schindl, A. et al. (2003). Direct stimulatory effect of low-intensity $670 \mathrm{~nm}$ laser irradiation on human endothelial cell proliferation. The British Journal of dermatology, 148(2), 334-6. DOI: 10.1046/j.1365-2133.2003.05070.x.

Sprouse-Blum, A. S. et al. (2010).
Understanding endorphins and their importance in pain management. Hawaii medical journal, 69(3), 701. Accessed from: http://www.ncbi.nlm.nih.gov/pubme d/20397507.

Zelin, D. A., Fatmawati, V. and Sulistyaningsih. (2019). Relationship between age and gender with low back pain complaints at Gamping 1 Sleman Yogyakarta Public Health Center. Aisyiyah Yogyakarta University. Accessible from: http://digilib2.unisayogya.ac.id/xml ui/handle/123456789/180. 